\title{
Scenario of haor vulnerabilities and other obstacles for sustainable livelihood development in Nikli upazila
}

\author{
P. K. Sarma \\ Bangladesh Agricultural University Research System (BAURES), Bangladesh Agricultural University, Mymensingh- \\ 2202, Bangladesh
}

\begin{abstract}
The study was carried out in haor areas situated in Nikli upazila under Kishoregong district to explore the socioeconomic vulnerabilities status of the people residing near deep haor areas and their dependency on its natural resources. Total 110912 local residents who depend on the wetland for their survival are poor, with an annual average per capita income Tk 3175, a literacy rate is 20.5\%.Total cultivable land 17912.75 hectares, fallow land 1007.59 hectares; single crop $79.32 \%$ and double crop land $20.68 \%$; land under irrigation $90 \%$. This paper also sheds light on the status of livelihood using resources and face problems are barriers to sustainable livelihood development. There haor based alternative activity is fishing (20\%) followed by duck rearing (3\%), Beef fating (6.6\%), The study find $71 \%$ households were found effectively landless of which about $55 \%$ were absolutely landless and $17 \%$ households were migrated and $78.9 \%$ haor households are suffered from food insecurity mainly because of landlessness, mono-crop cultivation, seasonal unemployment and natural calamities. The study suggests that the avenues for prospective coping strategies are to put a stop to existing leasing system of haor water bodies, making proper arrangements for creating alternative income generating activities throughout the year. Change the money lending system and taking preventives and curative measures for natural calamities.
\end{abstract}

Keywords: Socioeconomic, Indicator, Sustainable livelihood, Climate change

\section{Introduction}

The vast majority of Bangladesh's population depends for its survival on wetlands which cover more than half of the country's geographical area. They are home to some 25000 inhabitants most of whom are engaged in agriculture and subsistence fishing in the haor area. The population density of the haor basin is relatively low compared to the rest of the country, average 1000 population per village, household size stands at 6.5 , birth rate 3.2 and $35 \%$ of the population is below the age of 10 years. Haor is basically very low lying river basin area below the level of flood plain, which is also similar to swamp land covered by water almost 6(six) months of a year starting from the monsoon. These are important fishing ground and important area of boro rice cultivation of the country. The study area was covered in Nikli upazila under Kishoregonj district where floods and river erosion was recurrent and there was a presence of abject poverty. Fifty five percent populations were absolutely landless and the most marginalized living depends on the physical labor in agriculture field and fisheries. The water bodies are leased by government to rich people resulting poor people have no access to natural resources. The major economic sector of income and livelihood was agriculture and there was mainly mono cropping system. But the peculiar early flash floods often wash away the standing crops and people lose their harvest. Therefore, people were unable to come out of vicious poverty cycle. Due to extreme poor communication there was no quick transportation, spread of health facilities and educational institutions for population living at remote areas. Mound erosion by the wave of floodwater makes 50 to 100 families each year. Therefore, the present study has been undertaken specially;

i) to identify the factors associated with the vulnerability of the socioeconomic background in haor area

ii) to study the sustainable livelihood options and earning opportunities of the haor people.

\section{Materials and Methods}

The study was conducted in Nikli upzilla under Kishoregonj districts. A multi-stage random sampling technique was applied for this study. From 3 unions namely Chatirchar, Gurui and Dampara were selected randomly. Four villages were selected from these every union total $(3 \times 4) 12$ village using the 
same procedure. Total 144 households (12 households from every village) with a sampling intensity of were selected randomly for the survey study. A semi-structured questionnaire was used for the interview which includes various socioeconomic indicators such as literacy, landholding, occupation, family size, sanitation, decision making, and access on basic services and rights on haor resources and livelihoods options. Before preparing the final questionnaire, a preliminary one was developed in conformity was the objectives of the study. This draft schedule was pre-tested with a few selected households. Some parts of the draft questionnaire were improved, rearranged and modified in the lights of the practical experience gained from the pre-test. It was then finalized and questions were listed in logical sequence, so that the respondents could answer easily. The selected respondents were personally interviewed for collecting reliable data and other information. The data were analyzed by using the appropriate software such as SPSS, MS Excel etc as per objectives of the study.

\section{Results and Discussion}

\section{Scenario of the socioeconomic vulnerability faced by the haor people}

There were several vulnerabilities faced by haor people. An attempt was taken to determine the most pertinent vulnerabilities in this regard. Different socioeconomic vulnerability has been presented in Table 1.

Table 1. Socioeconomic vulnerability profile

\begin{tabular}{|l|c|c|c|c|c|}
\hline \multirow{2}{*}{ Vulnerability } & \multicolumn{2}{|c|}{$\begin{array}{c}\text { Number of respondent against each } \\
\text { of the three problem level }\end{array}$} & $\begin{array}{c}\text { Vulnerability } \\
\text { Index }\end{array}$ & $\begin{array}{c}\text { Rank } \\
\text { order }\end{array}$ \\
\cline { 2 - 5 } & 3 & 2 & 1 & & \\
\hline Village \& homestead erosion & 82 & 38 & 24 & 346 & 01 \\
\hline Flash flood & 79 & 37 & 28 & 339 & 02 \\
\hline Sanitation and hygiene vulnerability & 76 & 40 & 28 & 336 & 03 \\
\hline $\begin{array}{l}\text { Temporary migration for limited } \\
\text { Livelihood options }\end{array}$ & 78 & 35 & 31 & 335 & 04 \\
\hline Health insecurity & 59 & 64 & 21 & 326 & 05 \\
\hline Food insecurity & 63 & 51 & 30 & 321 & 06 \\
\hline Climatic change vulnerability & 71 & 29 & 44 & 315 & 07 \\
\hline Lack of financial support & 56 & 48 & 40 & 304 & 08 \\
\hline Marketing System & 53 & 46 & 45 & 296 & 09 \\
\hline
\end{tabular}

Note: 3 =High, 2=Moderate, 1=Low

It is found Table 1 that the first and foremost vulnerability faced by hoar people was the combination of chronic annual village and homesteaded erosion and occasionally destroying entire villages. Households spend BDT 5000-7000 to protect their households against the upcoming floods at the onset of the monsoon season. Many households are forced to migrate out during these months when much of village is underwater; households who remain in the often have no recourse but to take loans at high rates from unscrupulous moneylenders to pay the annual homesteaded protection costs.

The second vulnerability was flash flood .It was mentioned that a large amount of fertile and arable land lies in the haor in Nikli upazila under Kishoregonj district. The land in the haor areas are generally used for mono-crop cultivation, mainly boro rice in the winter. During the wet season, the entire haor region goes underwater and is transformed into floodplains for fresh water fishing. The high seasonality of the haor-based economy forces local people to remain out of work for a considerable period of time, and as a result, they suffer from food insecurity. It was the barrier to sustainable livelihood development. The third vulnerability was Sanitation and Hygiene vulnerability. It is evident from the survey findings that there are only $11 \%$ households, which have hygienic latrine; whereas in urban areas it is $60 \%$. The remaining $69 \%$ households have unhygienic latrines and the rest $20 \%$ households usually go for open defecation. Among those who are using toilets about $42 \%$ had their own toilets and about $19 \%$ of them were using 
community toilets. Using community toilets is an important finding for haor area as both suitable toilet technology and space for constructing toilets are problematic. Because, most of the households (81\%) reported that natural disaster, particularly flood is one of the main reasons for poor sanitation status in haor areas. River erosion, lack of road networks and standing water bodies are major challenges to secure livelihood in haor areas. Flooding, high water table, excessive rainfall and loose soil formation are the causes of overflow and collapse pit latrine. Every year most of the areas remain under water for about 4 to 7 months and it wipes out all existing sanitation system. Therefore, it becomes almost impossible for hardcore poor people to reconstruct toilets on a regular basis. Lack of proper awareness as mentioned by majority of the villagers (62\%), coupled with financial constraints, were some of the main reasons for poor sanitation coverage in the haor areas.

The fourth vulnerability was temporary migration due to few livelihood opportunities in haor area. Eighty percent households dependent on wage labour opportunities during the transplanting and harvest in mono crop season and fishing. Poor male family members were temporary migrate to nearest towns and sites such as Chittagong, Sylhet and Dhaka Kamrangirchar in search of work to mitigate their food, health , unemployment at lean period. Because there were no livelihoods option during the monsoons expect fishing and river erosion had emerged as a major threat to their life and sustainable livelihood development.

Fifth vulnerability was insecurity children die every year from presentable communicable disease, particularly from diarrhoea and pneumonia. Households rarely attempt to access government health care facilities especially during the monsoon. Because the poor in particular do not perceive that government services were there to serve their needs.

The sixth vulnerability was climate change. It has the potential to alter many of natural ecosystems in Bangladesh. Variability of climatic elements has already started affecting agricultural productivity, land use practices, life styles and livelihoods in the haor area. Livestock was directly and indirectly affected by climate change. It could directly affect milk production, growth and reproduction. It was projected to reduce poor people's livelihood assets and alter the path and rate of economic growth due to changes in natural resources, infrastructure and labour productivity. Since the economic impacts of climate will have to be borne by individuals, communities and the government, there is a need for evolving climate resilient development strategy involving all the relevant sectors and related institutions.

Household food sufficiency: The study revealed that the overall status of food security strategies for haor people in Nikli Upazila was not satisfactory although there were considerable avenues for providing prospective coping strategies for these people.

Food security vulnerability has been presented in Fig. 1. It shows that $79 \%$ households in the haor people in Nikli upazila are suffer from food insecurity. $42 \%$ households had less than 3 month, these households normality eat one meal and $37 \%$ up to 6 month and $18 \%$ whole year food sufficiency mainly because of landlessness, mono-crop cultivation, seasonal unemployment and natural calamities, according to a recent study. Three percent household had food surplus. The high seasonality of the haor-based economy forces local people to remain out of work for a considerable period of time, and as a result, they suffer from food insecurity. Food security strategies were unsatisfactory in the sense that the underlying factors for ensuring food security like education, employment opportunities, basic amenities for life including housing condition, sanitation facilities, production.

Primary Occupation of households in Nikli upazila: The major economic activities of the haor basin depend on agriculture. Rice is the main mono crop grown in the study areas. All rice crops are vulnerable to floods both during pre-monsoon and monsoon. About twenty seven $(27.12 \%)$ households were derived from agricultural production. Haor basin was also rich in fish resources, $20 \%$ households were directly involved in fishing. During the monsoon, the landless population depends mostly on fishing for their livelihoods. 


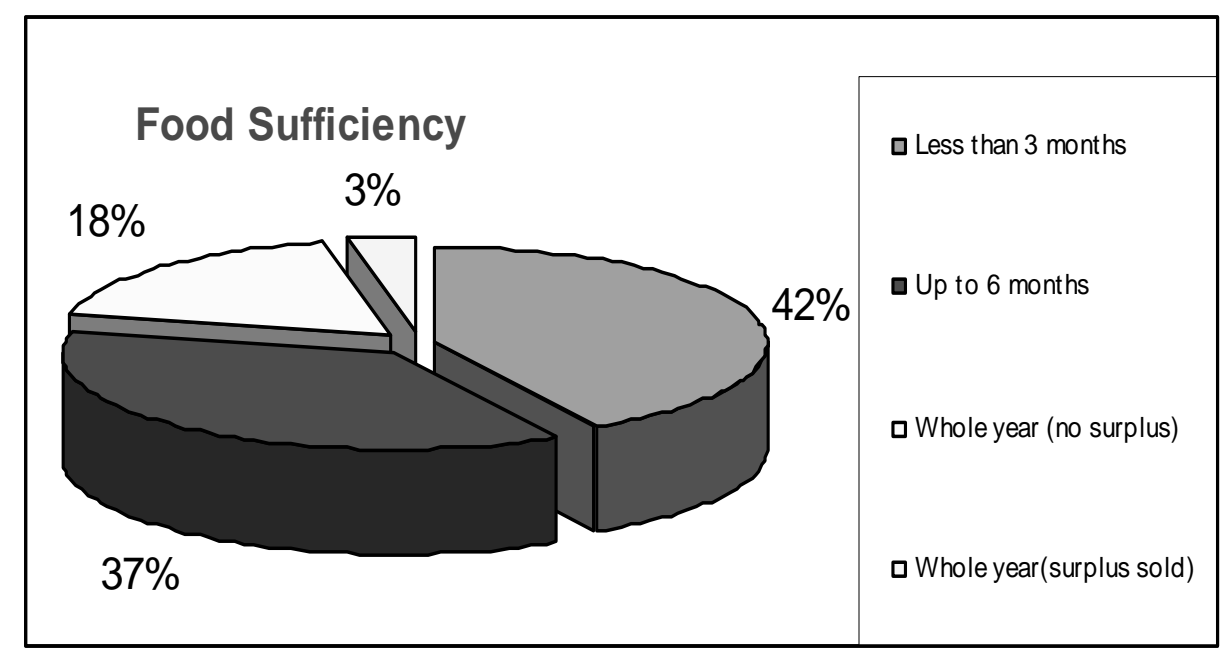

Fig. 1. Household food sufficiency

Navigational transportation is an essential part of social and economic activities of the haor, without which it is impossible for the population to carry on even their day to day activities.

Primary occupation was the socioeconomic condition to sustainable livelihood development of study areas. Table 2 shows that seasonal wage labour was the main occupation for majority people (37.5\%). Second occupation was labour $27.12 \%$ on agriculture farming and $20 \%$ was fishing. $85.62 \%$ households directly and indirectly depend on haor's natural resources. In spite of the abundance of water and land, agricultural and fishing was an essential livelihood option, poor families was not access on water and land unless they contract their services to the rich land and water loads (Jalmahals, ejaradars and Mohajon).

Table 2. A summary statement showing primary livelihoods options in Study area

\begin{tabular}{|c|c|c|c|c|c|c|c|c|c|}
\hline \multirow[b]{2}{*}{ Name of Union and Village } & \multirow[b]{2}{*}{ 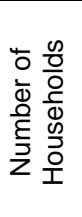 } & \multicolumn{8}{|c|}{ Primary occupation in haor areas } \\
\hline & & $\begin{array}{l}\bar{\Xi} \\
\frac{0}{\pi} \\
\frac{0}{0} \\
\frac{\pi}{3} \\
3\end{array}$ & $\begin{array}{l}\frac{0}{\frac{D}{C}} \\
\frac{\sqrt{n}}{11}\end{array}$ & 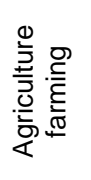 & 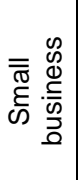 & 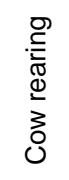 & 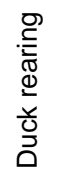 & 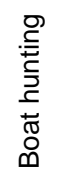 & $\begin{array}{l}\frac{\omega}{\Phi} \\
\stackrel{\Xi}{ \pm} \\
\end{array}$ \\
\hline \multicolumn{10}{|l|}{ Gurui Union } \\
\hline Parabajitpur & 219 & 60 & 73 & 34 & 5 & 20 & 7 & 11 & 9 \\
\hline Shatera & 321 & 179 & 14 & 81 & 13 & 26 & 3 & 0 & 5 \\
\hline Batirchar & 103 & 39 & 02 & 44 & 02 & 13 & 01 & 0 & 02 \\
\hline Gurui Majitpara & 259 & 103 & 13 & 89 & 17 & 23 & 8 & 2 & 4 \\
\hline Sub-Total & 902 & 381 & 102 & 248 & 37 & 82 & 19 & 13 & 20 \\
\hline \multicolumn{10}{|l|}{ Chatirchar Union } \\
\hline Purbo Hati & 283 & 87 & 69 & 76 & 07 & 19 & 09 & 05 & 11 \\
\hline East Hati & 215 & 73 & 75 & 49 & 02 & 13 & 01 & 02 & 0 \\
\hline West Hati & 339 & 103 & 86 & 101 & 11 & 17 & 13 & 03 & 05 \\
\hline Sub-Total & 837 & 263 & 230 & 226 & 20 & 49 & 23 & 10 & 16 \\
\hline \multicolumn{10}{|l|}{ Dampara Union } \\
\hline Kamalpur & 129 & 43 & 41 & 26 & 03 & 03 & 07 & 03 & 03 \\
\hline Aliapara & 203 & 93 & 41 & 55 & 02 & 09 & 02 & 1 & 0 \\
\hline Nawa kathankani & 287 & 101 & 73 & 68 & 03 & 19 & 11 & 05 & 7 \\
\hline Baburia & 139 & 40 & 19 & 47 & 0 & 13 & 09 & 02 & 09 \\
\hline Nabinpur & 217 & 97 & 41 & 66 & 01 & 05 & 02 & 01 & 04 \\
\hline Sub-Total & 975 & 374 & 215 & 262 & 09 & 49 & 31 & 12 & 23 \\
\hline Grand Total & 2714 & 1018 & 547 & 736 & 66 & 180 & 73 & 35 & 59 \\
\hline Percentage & & 37.5 & 20 & 27.12 & 2.4 & 6.6 & 3.0 & 1.0 & 2.2 \\
\hline
\end{tabular}

Source: Base line survey data (POPI Dream project) 2010 


\section{Suitable and preferred adaptable IGA for livelihood development of the haor Peoples}

The study carried out surveyed 144 households to measure their responses on alternative livelihood options. Out of total 144 households, the following options came from their response. The preference of the respondent was depends on their fusibility, accessibility and capacity on the basis of existing agricultural and non-agricultural intervention for income generating activities. Fig. 2 and 3 shows that Nikli inundates by water almost six month during rainy season and paralyzed most of the economic activating in haor area expects fishing. Thirty two percent household was liked fishing during the monsoon on the other hand $37 \%$ Households were interested on small business in off season. $17 \%$ households was interest on cow and beef fating on the other side $23 \%$ were interest on handicraft.

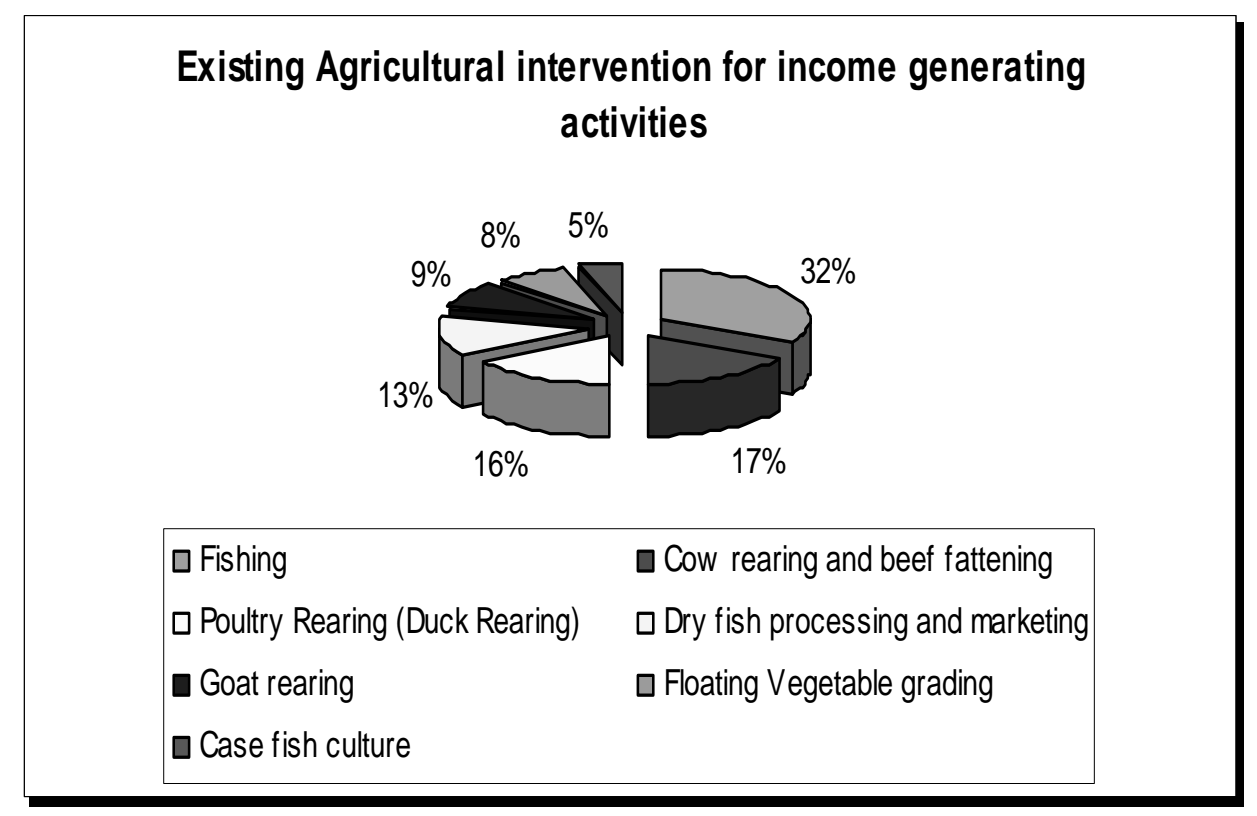

Fig. 2. Preferred Alternative IGA in agricultural intervention

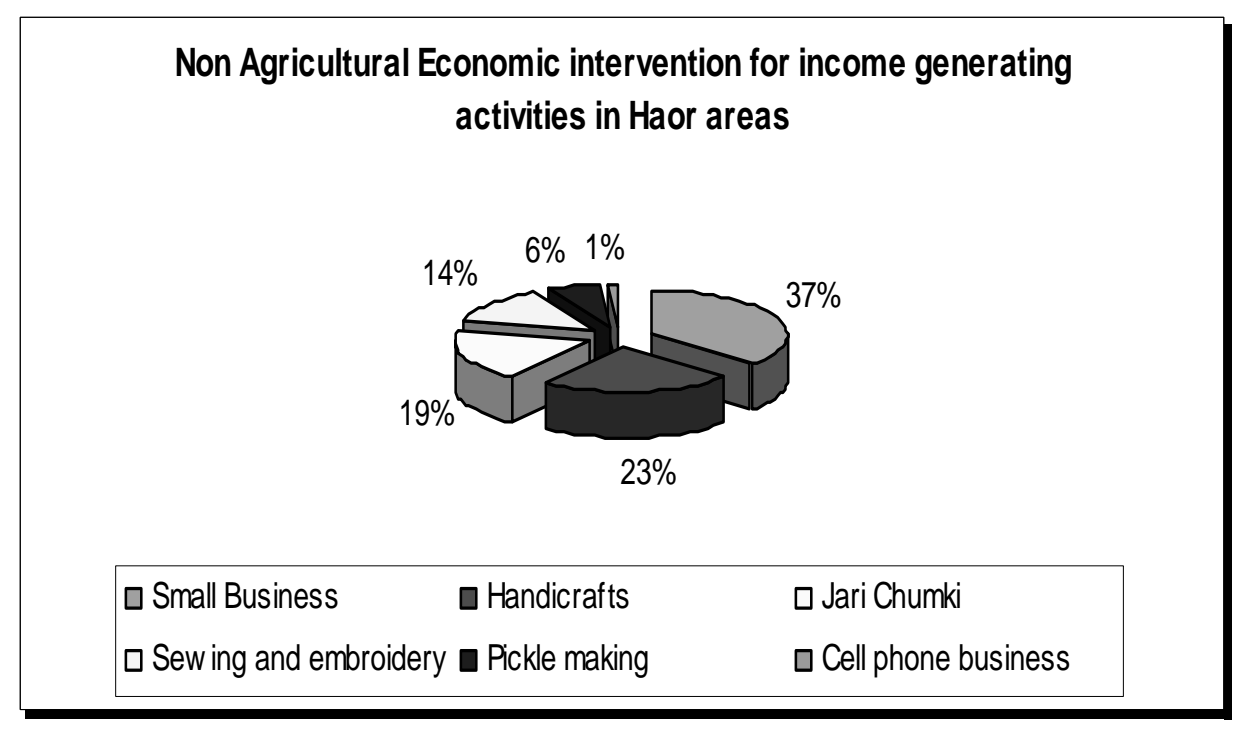

Fig. 3. Preferred Alternative IGA in non agricultural intervention 


\section{Economic significant of preferred IGA for sustainable livelihood development}

Increasing numbers of people in haor areas were sliding into poverty because of economic and social conditions. The situation is often characterized by lack of competitiveness, unemployment, unstable financial systems, and sustainable use of natural resources.

Floating gardens (baira) for sustainable livelihood: Lack of cultivatable space over the long flooding period is a vital concern in the haors of Nikli upzila and it restricts the livelihoods of the local communities. The present study aimed at the promotion of floating gardening, an age old agricultural system, in the haor area to overcome. This study will facilitate floating garden cultivation in the area including consumption/marketing of the products, and to sensitize the local vulnerable people towards this useful technique. Through appropriate capacity building and community organization this initiative will promote floating garden cultivation as a sustainable alternative livelihood in monsoon as well as in winter through seedling raising and vegetable gardening. The research will the feasibility of floating vegetable garden introduced in the study area for the enhancement of livelihood, thus the food security of the vulnerable people will be promoted.

Duck rearing for sustainable livelihood: Duck rearing is one of the major income generation opportunities in the study area. About $16 \%$ of the household's livelihood activity is duck rearing, which is depending on haor. From selling duck and eggs most of the households earn BDT1500 per month. But duck supply, diseases control, Credit facilities, and markets are the barriers to sustainable development through duck rearing. Agricultural resources of which scavenging duck rearing is considered to have potential both for poverty alleviation and food production, especially for the rural poor women. Ducks eggs and meat produced from scavenging ducks are considered to be organic products and are completely free from hormones and antibiotics

Fishing for sustainable livelihood: Fishing related activities such as capturing fish, fish trading, fish drying and net weaving is the one of the major alternative livelihood activities in the haor areas. The average annual income from this sector is about BDT 5400 but illegal harvesting, unsustainable collection of fish and illegal leasing system of water body is the barricade to sustainable livelihood development.

Sewing and embroidery for alternative sustainable livelihood: Sewing and embroidery (including tilla work, crochet, weaving) is the alternative livelihood common activities of haor area especially for women the most of the people have been designed with the resources, skills, abilities and interests of the people concerned. Since the income from these sources are seasonal, it becomes imperative for the rural poor and marginalized to earn through these multiple activities for a reliable income throughout the year but lack of training and credit facilities, lack of product marketing and social issue was obstacle to sustainable livelihood development.

Jari chumki for alternative sustainable livelihood: Jari chumki is a famous and potential profitable income generating activities of haor people especially women. Its require certain level of skill training provided by the experienced local trainers. Shari has been designed by embroidery machine and then it is being hand made stitched using different colorful and attractive threat, jari and chumki. Local vender supplies the plain shari along with necessary materials to the selected women to complete the work. Local vendor collect raw materials from benaroshi palli in Mirpur and supplied finished product to the same or Dhaka, Gulshan, Banani, Mirpur and Gaushia super market. Every people earn BDT 200-250 per day from their house. It is the most important alternative livelihood in study area but some barrier to develop this sector such as lack of training, no forward and backward market linkage, no bargaining power. 


\section{Conclusion and Recommendations}

Haor characteristically has plenty of agriculture land and abundance of fish. But both are governed and controlled by local elites and rich people. Huge khash land all around the haor and many of the large khas lands are very close to many poor households, but unfortunately they don't have access to these lands due to lack of ownership. The local rich people's community does not allow them to lease the land and they don't even have the technological / initial input support to plough the lands. On the other hand during the winter season each large water body of Nikli haor basin confine into small water body full of fishes. Local rich people took illegal lease of all the water bodies from Government to form a so called fishermen group due to lack of distribution law but in reality the poor fishermen have no access to these water bodies. If the poor people could get the opportunity to catch fish in these water bodies, they could easily earn a good amount of money by selling it. As a result the available haor resources are unable to improve the lives of extreme poor people in these areas. Government and NGOs also failed to address the basic need of education, health, nutrition, family planning and recreation of the vulnerable haor people especially the children and women. The study emphasis to work with the poor peoples' rights and access to the haor natural resources and protect and support them through their inclusion in national policy and system.

In this situation, the flowing recommendations may be made to sustainable livelihood development.

a) Prepare a master plan for the comprehensive development of haors integrating all sectors. e.g. water resources, fisheries, navigation, forestry, wetland and khas land distribution.

b) Develop an early warning system for flash floods in the haor basin to reduce the extent of flood damage.

c) Develop hard-surface submersible roads, where feasible, to quicken the transportation of harvests using mechanical transports.

d) Plant hijal, koroch and other verity of trees to restore the ecological balance and protected homesteads from river erosion of the haor basin in Nikli upazila.

e) Recommended conducting more research on haor economy focusing on identifying the problems in different dimensions and discovering prospects in the corresponding fields for pragmatic and urgent policy implications; comparative study with other people in other haors to share experience and other coping strategies in food security; design advocacy materials on what to do and not, what to do during natural calamities and lean season.

f) Need asset transfer among the poor households because they were selling productive assets such as livestock in a common coping mechanism during times of a climatic stress or shock. Inability to access such assets traps the in a persistent cycle of chronic poverty.

g) Need to cash/seed money transfers among the poor family. Predictable cash transfer could play an important role in mitigation the vulnerability of the chronic poor of climate related shocks and stresses. It was a vulnerability safety net in haor area.

\section{References}

Ahmad, Alia, Mahabub Hossain and Manik Lal Bose. 2005. Inequality in the Access to Secondary Education and Rural Poverty in Bangladesh: An Analysis of Household and School Level Data | Lund, Sweden: Lund University, Department of Economics, Working Papers, No. 2005:36 (June).

Ahmed, Ahsn Uddin. 2006. Bangladesh: Climate Change impacts and Vulnerability-A synthesis" Dhaka: GoB, MoEF, Department of Environment, Climate change cell (July). 
Ahmad, Qazi Kholiquzzaman. 2006. Poverty and water security in Bangladesh: a conceptual framework | Asia Pacific Journal on Environment and Development, Vol. 12, No. 1. pp. 1-20.

BBS. 2006. Bangladesh Bureau of Statistics, Ministry of Planning, Government of the People's Republic of Bangladesh.

Base line Survey. 2010. Development and Rehabilitation of Extreme poor through Alternative means project: People's oriented programme implementation, Dhaka, Bangladesh.

Chowdhury, Q., Rashid, A.Z.M.M. and Afrad, M. 2004. Socio-Economic Significance of Reed Forests in a Rural Community: A Case Study from the Greater Sylhet Region of Bangladesh. Small-scale Forest Economics, Management and Policy 3:121-130.

Hoque, M.A., Sarkar, M.S.K.A., Khan, S.A.K.U, Moral, M.A.H. and Khurram, A.K.M. 2006. Present status of Salinity Rise in sundarbans area and its effects on sundari (Heritiera fomes) Species. Research. J.Agr.Biolog.Sci. 2:115-121.

Islam, M.A., Chowdhury, N.K. and Haque, M.R. 2005. Socio-Economic Baseline of Pagnar and Sanuar-Dakuar haors, Bangladesh: Published by IUCN, Dhaka, Bangladesh.

Mozumdar, L., Farid, K.S., Ahmed, J.U. and Rahman, M.W. 2009. Broiler farming: An approach to improvement rural livelihood. J. Bangladesh Agril. Uni.7(2): 395-402.

Rana, P.M, Islam, S.S.M., Akter,.S., Alam, S.M. 2009. Haor based livelihood decency of a rural community: A study on Hakaluki haor in Bangladesh. Proc. Pakistan Acad. Sci. 47(1). pp. 10. 